\title{
Rhodococcus equi
}

National Cancer Institute

\section{Source}

National Cancer Institute. Rhodococcus equii. NCI Thesaurus. Code C86719.

A species of aerobic, Gram positive, rod and cocci shaped bacteria assigned to the phylum Actinobacteria. This species has a pink color, is urease positive and grows on glycerol. R. equi is a lung pathogen that can infect grazing animals and immunocompromised people. 